IZA DP No. 10131

Measuring Women's Empowerment in Rwanda

Abdou Musonera

Almas Heshmati

August 2016

Forschungsinstitut zur Zukunft der Arbeit Institute for the Study of Labor 


\title{
Measuring Women's Empowerment in Rwanda
}

\author{
Abdou Musonera \\ MIFOTRA-SPIU
}

Almas Heshmati

Jönköping University

and IZA

\section{Discussion Paper No. 10131 \\ August 2016}

\author{
IZA \\ P.O. Box 7240 \\ 53072 Bonn \\ Germany \\ Phone: +49-228-3894-0 \\ Fax: +49-228-3894-180 \\ E-mail: iza@iza.org
}

\begin{abstract}
Any opinions expressed here are those of the author(s) and not those of IZA. Research published in this series may include views on policy, but the institute itself takes no institutional policy positions. The IZA research network is committed to the IZA Guiding Principles of Research Integrity.

The Institute for the Study of Labor (IZA) in Bonn is a local and virtual international research center and a place of communication between science, politics and business. IZA is an independent nonprofit organization supported by Deutsche Post Foundation. The center is associated with the University of Bonn and offers a stimulating research environment through its international network, workshops and conferences, data service, project support, research visits and doctoral program. IZA engages in (i) original and internationally competitive research in all fields of labor economics, (ii) development of policy concepts, and (iii) dissemination of research results and concepts to the interested public.
\end{abstract}

IZA Discussion Papers often represent preliminary work and are circulated to encourage discussion. Citation of such a paper should account for its provisional character. A revised version may be available directly from the author. 
IZA Discussion Paper No. 10131

August 2016

\section{ABSTRACT}

\section{Measuring Women's Empowerment in Rwanda}

This study examines the determinants of women's empowerment in Rwanda using data obtained from DHS 2010. A regression analysis is used to investigate the association between women's empowerment and its covariates. The study also uses a multinomial logistic regression to assess what determines households' decision-making and attitudes towards physical abuse of spouses. Variables of sources of empowerment such as education and media exposure were found to have a net positive association with women's empowerment while other variables such as residence and the age at first marriage were negatively associated with women's empowerment. Further analysis showed that the effects of education, age of the respondent, wealth and the number of children ever born remained strong conditions which effected households' decision-making and attitudes about physical abuse. In general, therefore, it seems that for women to fully realize their potential and rights, specific emphasis should be put on variables that increase their access to resources and knowledge such as education, employment for cash and media exposure but variables that are negatively associated with women's empowerment such as higher age at first marriage should also be taken into account.

JEL Classification: D63, D91, I15, I25, J12

Keywords: women's empowerment, physical abuses, household decision-making, Rwanda

Corresponding author:

Almas Heshmati

Jönköping International Business School

Jönköping University

P.O Box 1026

SE-551 11 Jönköping

Sweden

E-mail: almas.heshmati@gmail.com 


\section{Introduction}

In recent years, a range of organizations have increasingly shown commitment to women's empowerment; they have also realized that empowering women is a win-win situation that benefits both women and society. Golla et al. (2011) claim that women's economic empowerment is fast becoming a key instrument in promoting their abilities to achieve their rights and well-being which subsequently reduces household poverty and increases economic growth, productivity and efficiency.

There is a growing body of literature which recognizes the social and economic importance of involving women in the development process. While some of this focuses on spill-over benefits resulting from allowing women to have greater control over resources and the impact that this has on the health and education of their children and on better well-being prospects for future generations (the World Bank Poverty, Inequality and Gender Group, 2012), other literature pays particular attention to the relationship between women's empowerment and health outcomes (see, for example, Abadian, 1996; Bloom et al., 2001; Fotso et al., 2008; Larsen and Hollos, 2003; Lee-Rife, 2010; Patrikar et al., 2014; Wypij and Gupta, 2001; Sado et al., 2014; Schuler et al., 1996; Schuler et al., 1997; Upadhyay and Karasek, 2012; and Upadhyay et al., 2014).

While a great deal of previous literature on women's empowerment focused on what determines two indicators of their -- household decision-making and self-esteem (ElHalawany, 2009; Ghuman et al., 2004; Kishor, 2000; Kishor and Subaiya, 2008; Mahmud and Tasmeen, 2014; Mahmud et al., 2012; Malhotra and Mather, 1997; and Sado et al., 2014) -- other studies have described the role of women's access to finance and labor force participation in the empowerment process (Ali et al., 2013; Allendorf, 2007; Allsopp and Tallontire, 2014; Faridi et al., 2009; Ganle et al., 2015; and Naqvi and Shahnaz, 2002). Together these studies provide evidence that measurement issues still exist in the process of translating 'evidence of empowerment' and 'access to sources of empowerment' into agency especially using cross-sectional survey data (Kishor and Subaiya, 2008) and thus highlight the need for going beyond structural and merely simplistic factors (family, social and economic) to be able to measure women's empowerment in a comprehensive way (Malhotra and Mather, 1997). In the same vein, Ghuman et al., (2004) argue that difficulties in measuring women's empowerment call for an in-depth understanding of gender relations by spending enough time in the community and doing pre-testing.

There is evidence of positive effects of women's empowerment from around the world. There is also internationally recognized knowledge about channels of empowerment and effects. For example, the World Bank Poverty and Gender Group Report (2012) shows that women's control over resources creates spill-over benefits that have a significant positive impact on the health and education of children thus leading to better well-being prospects for future generations. Similarly, Golla et al. (2011) highlight women's empowerment as one of the key drivers in promoting their abilities, rights and well-being which subsequently reduces poverty and increases economic growth, productivity and efficiency. However, very few empirical studies use Rwandan data, for example, Ali, Deininger and Goldstein (2014) in their study on environmental and gender impact of land tenure regularization in Africa and Mukashimana and Sapsford (2013) in their study on martial conflicts in Rwanda. 
In this study we investigate the determinants of women's empowerment in Rwanda, especially what determines household decision-making and self-esteem. We address two questions: Whether variables of sources of empowerment (education, employment for cash, regular media exposure and wealth) have a significant positive association with women's empowerment. Some variables of 'setting' (age of the respondent and children ever born) are positively related to women's empowerment while other variables such as residence and the age at first marriage are negatively associated with women's empowerment.

Data used in the current study are from the Demographic and Health Survey (DHS) conducted in 2010 by the National Institute of Statistics for Rwanda (NISR, 2010, 2013). Respondents were married women aged between 15 and 49 years. A multiple regression analysis was used to empirically analyse the determinants of women's empowerment in Rwanda. A multinomial logistic regression was also used to examine the relationship between household decision-making, justifications about wife beating and women's empowerment covariates.

We found evidence that women's empowerment can be achieved through providing education, media exposure, labour force participation, shifting negative traditional cultural norms (such as giving respect to women with more children, marrying girls at an earlier age) and by focusing on integrated development.

The rest of this paper is organized as follows. The next section reviews literature on the relationship between women's empowerment and health outcomes, labour force participation, access to finance, cultural norms and determinants of women's empowerment. Section 3 describes the empirical strategy. After an overview of the findings in Section 4, these findings are discussed in Section 5. The last section gives concluding remarks.

\section{Literature review}

We briefly review literature from three perspectives. The first dimension is concerned with the definitions of women's empowerment. The second dimension pertains to the determinants of women's empowerment and the association between their empowerment and different health outcomes, cultural norms and the influence of labour force participation and women's access to finance on their empowerment. The third strand relates to the conceptual framework.

\subsection{Definitions of women's empowerment}

Several attempts have been made by authors to improve upon definitions of women's empowerment. Empowerment is a continuous, phased and relational process that occurs across scales and pathways (Goldman and Little, 2014). Allsopp and Tallontire (2014) define empowerment as a dynamic process that follows a series of sequential steps in which ownership of one type of power increases the likelihood and the ability to exercise other forms of power thus creating a positive 'power spiral'. 
Kabeer (2005) views the empowerment concept as revolving around the idea of power to make a choice and conceptualizes disempowerment as the denial of the possibility of making a choice by people who deserve to. Put differently, empowerment can be conceptualized as a dynamic process by which people who were previously deprived of the ability to make a choice gain such an ability. For this to happen and the choice to be successful, there should be the capacity or possibility to choose otherwise.

Empowerment is a person's potential to make functional choices, that is, the ability to translate choices into desired outcomes and actions (Alsop and Heinsohn, 2005). Kishor and Subaiya (2008) defines empowerment as a process that enables powerless people to have control over the circumstances of their lives and the idea behind this is not power to dominate others but power to achieve goals and ends and this process appears to be affected by different social, cultural and economic factors (Upadhyay et al., 2014)

Empowerment is a process which results from two milestones -- agency and opportunity structure. Agency is defined as the potential to make effective choices and the opportunity structure is conceptualized as the environment/context in which individuals exercise agency or pursue their interests including institutional, political and social contexts and societal informal rules and norms (Samman and Santos, 2009).

However, three main concepts should be cautiously analysed while defining and measuring empowerment -- the existence of choice (whether a choice exists), use of choice (whether individuals use a chance to choose) and the achievement of choice (whether the choice generates desired outcomes/results) (Samman and Santos, 2009).

Choice can either be the first choice or 'strategic life choices' (choice of livelihood, choice of residence, choice of a partner, whether to have children or not and the number of children to have, the one who has rights over the children, freedom of movement and the choice of friends). A second order choice entails choices that are not strategic to life (Kabeer, 1999a and 1999b). The potential to make strategic life choices can be conceptualized in the form of three dimensions or 'moments', that is, resources (pre-conditions to empowerment), agency (process) and achievements (outcomes). According to Kabeer (2005) agency can be either passive (action taken when the choice is limited), active (meaningful and purposeful choice), greater effectiveness of agency (carrying out their roles and responsibilities) and transformative (capacity to act on the restrictive aspects of roles and responsibilities and being able to challenge them).

\subsection{Some major theories on women's empowerment}

In the new global economy, women's empowerment has become a central issue for countries to be able to achieve development goals such as economic growth, poverty reduction, health, education and welfare (Golla et al., 2011). Of late there has been renewed interest in the relationship between women's empowerment and health outcomes. Some of these theories focus on women's empowerment and healthcare use (Bloom et al., 2001; Fotso et al., 2008; Lee-Rife, 2010; and Sado et al., 2014). Women's empowerment has been identified as a driving force in ensuring improved maternal healthcare (Sado et al., 2014). The place of 
delivery is mainly influenced by wealth, education and demographic and health covariates while autonomy, decision-making and freedom of movement are found to have little influence on the place of delivery (Fotso et al., 2008).

Women's involvement in decision-making and their attitudes towards negative cultural norms such as domestic violence have been highlighted as the main determinants for the use of maternal healthcare services (Sado et al., 2014).

Overall these studies highlight the need for policy actions that focus not only on education but also on other factors that are likely to enhance health status with the aim of improving health outcomes for women and their families.

However, a majority of these maternal health studies mainly focus on women's individuallevel variables such as age, education and income or community level factors and little attention is paid to the effect of bargaining power within households. Thus, without an unbiased and accurate measurement of power, decision-making processes and different paths through which they affect reproductive health outcomes, our understanding of the covariates of maternal health and child health are incomplete.

A large and growing body of literature has investigated the association between women's empowerment and fertility preferences (Abadian, 1996; Larsen and Hollos, 2003; Patrikar et al., 2014; Al Riyami et al., 2004; Schuler et al., 1996; Upadhyay and Karasek, 2012; and Upadhyay et al., 2014). Fertility preferences are mainly influenced by women's resource control, freedom of movement and freedom from household domination. The most striking result to emerge from the data is that all three variables exert little influence on contraceptive use (Schuler et al., 1996). The results are not consistent with regard to the number of children because some of the studies show a negative relationship between women's empowerment and the number of children, while others show that there is a positive connection between women's empowerment and fertility preferences (having children or not). A few studies also show that there is no connection between empowerment and fertility preferences (Upadhyay et al., 2014).

Women's access to fundamental freedoms and increased access to and control over resources improve not only their welfare but also contribute to reduction in fertility (Abadian, 1996). Women's autonomy, as measured by the level of education, age at first marriage and spousal age difference, is inversely associated with fertility (Abadian, 1996). Wealth is likely to increase not only access to healthcare and in reducing child mortality rates but also in increasing access to education and reducing child labour through increased chances for children to attend school (Abadian, 1996). Larsen and Hollos, (2003) postulate that the progression from having one child to the next declines owing to the status of women especially free partner choice, women's education and household wealth. Attitudes towards wife beating have a negative relationship with a small ideal number of children while household decision-making and positive attitudes towards violence are strongly associated with a larger ideal number of children (Upadhyay and Karasek, 2012). However, these findings suggest the need for further research to determine the most appropriate empowerment measures that are context specific. These findings also highlight the need to 
emphasize not only on factors enhancing health outcomes but also on other factors that are driving forces for an improved quality of life.

A lot of previous research on women's empowerment has mainly focused on the determinants of women's empowerment indicators which mainly include household decision-making and self-esteem (El-Halawany, 2009; Ghuman et al., 2004; Kishor 2000, Kishor and Subaiya, 2008; Mahmud and Tasmeen, 2014; Mahmud et al., 2012; Malhotra and Mather, 1997; Sado et al., 2014; Trommlerova et al., 2015). Measuring a dynamic process like women's empowerment necessitates indicators that measure the end result, that is, indicators that measure evidence of empowerment and indicators that measure various sources of empowerment as well as indicators for measuring the setting of empowerment (Kishor, 2000). Potential sources of empowerment are defined as those factors which provide a basis for empowerment including knowledge, media exposure and access and control over resources (as explained by being employed for cash). Indicators of setting for empowerment are those conditions that reflect both the past and current environments of the respondents and these factors appear to condition the views and the chances available for women (Kishor and Subaiya, 2008).

Empowerment is largely determined by education, age, economic activity, country of residence and being a polygamous married male (see Trommlerova et al., 2015). Kishor and Subaiya, (2008) argue that social development indicators such as education are positively associated both with taking decisions alone and jointly. They further show that women's empowerment is largely determined by access and control over resources, indicators of sources of empowerment (educational attainment, employment for cash and media exposure) and a setting of empowerment including indicators such as a higher age at first marriage and smaller spousal age difference.

A positive association has been found between household decision-making and other factors related to women's economic empowerment (Sado et al., 2014). Household wealth is a strong determinant of resource control but it has a significant negative association with women's overall household decision-making and the association between covariates and different empowerment indicators was not consistent (Mahmud et al., 2012). Factors associated with sources of empowerment (employment, education and wealth status) had higher explanatory powers than factors related to the setting of empowerment (age and family structure) (see Sado et al., 2014).

Mahmud et al., (2012) show that there was no association between women's freedom of mobility and household wealth. This is not surprising because freedom of mobility is high for the poorest women who are always obliged to travel outside their homes to participate in the labour force. They further state that women from wealthier households are less likely to have a say in household decision-making; instead they tend to have the view that their voice is not relatively worthwhile but there is a high likelihood of their having access to cash for spending. Conversely and surprisingly, residing in an extended family was found to increase the likelihood of a woman having high decision-making powers and self-esteem (Sado et al., 2012). 
However, there are variations and differences in the nature and determination of financial, social and organizational dimensions which imply that women's control over one of the family aspects does not necessarily imply control over other aspects. For example, while education and employment are the main determinants of a woman's input in financial decision-making, these variables exert no influence on social and organizational related household decision-making.

Three important themes emerge from studies on the determinants of women's empowerment discussed so far: (i) measurement issues still exists while translating 'evidence of empowerment' 'and access to sources of empowerment' into agency especially using crosssectional survey data; (ii) it is very important to go beyond structural and merely simplistic factors (family, social and economic) to measure women's empowerment in a comprehensive way; and (iii) these difficulties in measuring women's empowerment call for an in-depth understanding of gender relations by spending enough time in the community and doing pre-testing.

\subsection{Conceptual framework}

Women's empowerment is achieved through two pathways (different ways of being and experience sharing) that operate individually. However, it was found that a woman's potential to attain positive outcomes is accelerated when she possesses more than one pathway (Allsopp and Tallontire, 2014). The level of empowerment in a village depends on different pathways (personal, economic and political) and linkages across scale ranging from personal bodies and household relations to the community (Goldman and Little, 2014). Kabeer (1999a and 1999b) points out that women's empowerment is conceptualized as a three dimensional process that encompasses resources or pre-conditions of empowerment, agency or process and achievements that measure outcomes. Kabeer further argues that women's potential to exercise strategic life choices is conceptualized in terms of three dimensions or moments for the social change process to be completed:

Resources (pre-conditions) > agency (process) > achievements (outcomes)

Kabeer (2001) and Kishor (2008) conceptualize empowerment in terms of agency, resources and achievements. Kishor and Subaiya (2008) conceptualizes the empowerment process in terms of evidence and sources of empowerment but acknowledges that the extent of translating evidence on empowerment and access to sources into agency and the capacity to make a choice and act upon it is not yet measured. Kishor (2000) and Samman and Santos (2009) claim the importance of three indicators of empowerment: source, evidence and setting.

Measuring the empowerment process is conceptualized at different levels, in different domains and at different levels of an actor's life (Alsop and Heinsohn, 2005). These domains include the state in which people are civic actors, the market in which persons are economic actors and society in which they are social actors. These domains also contain sub-domains which in turn comprise of different levels. For example, the market domain is composed of the sub-domains of credit, labour, production and the consumption of goods. Society 
comprises of family and community. There also exist three levels at which empowerment is exercised: the local level which is contiguous with people's residence, the intermediate level which is between the residential and national levels and finally, the national level which is thought to be the furthest from an individual.

Kabeer (2005) claims that the empowerment concept can be measured through three interlinked dimensions -- agency, resources and achievements. Agency is central to the concept of empowerment and is defined as the process by which a choice is made and transformed into effect. Resources are conceptualized as a medium through which agency is exercised and achievements are conceptualized as outcomes of agency. Similarly, Rowlands (1997) and Samman and Santos (2009) highlight that agency and empowerment are interrelated concepts, that is, empowerment does not happen in a vacuum. In the categorization of power, Rowlands classifies empowerment as a process by which people gain power over (resistance to manipulation), power to (ability to create new possibilities), power with (ability to be an actor in a group) and power from within (enhancing self-respect and selfacceptance).

Alsop and Heinsohn (2005) postulate that the level of empowerment for a given person is associated with his/her personal capacity to make meaningful and purposive choices (agency) and the institutional environment in which the choices are made (opportunity structure). Similarly, Samman and Santos (2009) argue that empowerment occurs along different dimensions including economic, social-cultural, legal, political and psychological. They further find that agency is exercised at different levels - the micro level (household), meso level (community) and macro level (state and the country). The empowerment model consists of five stages: motivation for action, empowerment support, initial individual action, empowerment program and institutionalization and replication (Kar et al., 1999).

\section{Empirical strategy}

This study set out to assess what determines women's empowerment in Rwanda using household decision-making and self-esteem indicators. The results will extend our knowledge of variables which are a source of empowerment and setting of empowerment. The data used are from the 2010 Demographic and Health Survey (DHS) by the National Institute of Statistics for Rwanda (NISR, 2010, 2013). The respondents were married women aged between 15 and 49 years. A multiple regression analysis was used to empirically analyse the determinants of women's empowerment in Rwanda. A multinomial logistic regression was used to examine the relationship between household decision-making, justifications for wife beating and women's empowerment covariates.

\subsection{Model specification}

\subsubsection{Women's empowerment and its covariates}

In order to provide a proper specification of the model and to conduct a sensitivity analysis of the results, the baseline model was specified in three ways: 
- $\quad$ CEI = f(Age, Educ Wealth, PaidWork, Resid, Media, Children, AgeFM).

- $\quad$ DEC.IND = f(Age, Educ, Wealth, PaidWork, Resid, Media, Children, AgeFM)

- $\quad$ EST.IND = f(Age, Educ, Wealth, EmpCash, Resid, Media, Children, AgeFM)

where CEI is the cumulative empowerment index which is obtained by combining the decision-making and self-esteem indices. DEC.IND is the decision-making index. EST.IND is the self-esteem index. Age in age cohorts represents the age of the respondents classified in four categories (15-19, 20-29, 30-39, and 40-49). Educ is a respondent's education level (no-education, primary education, secondary education and higher education). Wealth is a respondent's wealth that falls in five categories (poorest, poorer, middle, richer and richest). EmpCash is defined as a respondent's employment status where the respondent can be either employed for cash or not. Resid is the residence of a respondent (either in an urban area or rural area). Media is media exposure that is defined as either regular media exposure or nomedia exposure. Children is categories of children ever born (None, 1 or 2, 3 or 4, 5 and above). AgeFM represents the age of a respondent at first marriage. This is classified into three groups (less than 18, 18-24, 25 and above).

\subsubsection{Household decision-making and attitudes towards physical abuse}

Questions to find out who had the final say on what to do with a respondent's earnings, respondent's healthcare, large household purchases and visits to family or relatives were asked during the survey. Different responses for each question were labelled as: others (0), joint decision (1) decision alone (2). Then each decision was used as a dependent variable to determine the likelihood of that decision being taken given different covariates of women's empowerment using a multinomial logistic regression.

Moreover, attitude towards physical abuse (in the survey labelled as wife beating) was investigated using five questions that were asked to know the circumstances under which wife beating is justified: going outside without permission, neglecting children, arguing with husband, burning food and refusing to have sex with her husband. Responses to the questions were labelled as: Yes (1), No (2) and others (0). Then, a multinomial logistic regression was used to regress each decision on different covariates of women's empowerment to determine odds in their ratios. The covariates used were the same as those used in the previous model with women's empowerment, that is, age group, children ever born, education, media exposure, employment for cash, residence, wealth and age at first marriage.

The baseline model is associated with the models used by Kabeer and Subaiya (2008), Sado et al. (2014), Mahmud et al., (2012) and Mahmud and Tasmeen (2014). Kabeer and Subaiya (2008) point out that women's empowerment is largely determined by access and control over resources, indicators of sources of empowerment (educational attainment, employment for cash and media exposure) and a setting of empowerment including indicators such as a higher age at first marriage and smaller spousal age difference.

The main weakness of Kabeer and Subaiya's (2008) study is the paucity of data on all indicators of women's empowerment (only data on household decision-making and attitudes 
towards wife beating were available) and some of the covariates that were used in previous studies. Another weakness of their study is that the results might have been affected by measuring women's empowerment using data which contained missing values.

\subsubsection{Data and variables}

Data used in the current study were obtained from the Demographic and Health Survey (DHS 2010). The respondents were married women aged between 15 and 49 years. Women empowerment was investigated using two indicators -- household decision-making and attitudes towards gender roles.

\section{A. Dependent variables}

The dependent variables used in this study were the cumulative empowerment index (the main component) and its constituents, that is, the decision-making index, self-esteem index, decision-making (alone and jointly) and agreement with wife beating justifications (yes or no).

\section{Decision-making index}

Respondents were asked different questions regarding who had the final say on different household decisions such as respondent's healthcare, visits to family and relatives, large household purchases, decision on what to do with the money that the husband earned. The responses were coded ' 1 ' if the decision was taken by the respondent alone, (2) if the decision was jointly taken by the respondent and her husband, (3) if the decision was taken by the respondent and another person, (4) if the decision was taken by the husband/partner alone, (5) if the decision was taken by someone else, and (6) for others.

The decision-making index was computed by assigning scores to different responses. A (2) was assigned to every response where the decision was taken alone by the respondent, (1) was assigned to every response where the decision was jointly taken and $(0)$ otherwise. Then individual scores for the different decisions were added to get total scores out of ten (ten is the maximum score), that is, 2 (marks maximum/decision) $* 5$ questions.

\section{Self-esteem index}

Respondents were asked questions about their attitudes towards gender roles and norms. Respondents were asked whether wife beating was justified under one of the following circumstances:

- When she goes out without telling her husband.

- If she neglects children.

- If she argues with her husband.

- If she refuses to have sex with her husband.

- If she burns the food.

Responses were coded (1) if the respondent said (yes) and (0) if the respondent said (no). 
In the current study, the scores assigned to different responses were: (1) was assigned to every response where the respondent said (no) and (0) to every response where the respondent answered (yes). Finally, individual scores were added to get the total scores out of five (maximum 1 mark $* 5$ questions).

The value of either the decision-making index or the self-esteem index should fall in the interval (0-1) or alternatively ( 0 per cent -100 per cent).

\section{Cumulative empowerment index}

While conducting DHS, the respondents were not asked to assign weight to different indicators of women's empowerment. Therefore, we assumed that all the indicators had the same weight and then computed the cumulative empowerment index using a non-parametric method as indicated by:

$\mathrm{CEI}=(\mathrm{W} 1 *$ Dec.Index $+\mathrm{W} 2 *$ S.Est.Index $) / 2$

where W1 and W2 are weights assigned to each women's empowerment indices which reflect weights attached to each indicator in the aggregation.

Dec.Index is the decision-making index which was obtained by adding the scores obtained from different responses on different questions about household decision-making.

S.Est.Index is the self-esteem index which was obtained by adding scores of different responses about respondents' attitudes towards justifications for wife beating.

The same approach for computing women's empowerment has been by authors in previous studies such as by Lee-Rife (2010); Mahmud and Tasneem (2014); Mahmud et al. (2012); Patrikar et al. (2014); Sado et al., (2014); Sultana and Hossen (2013); Upadhyay and Karasek (2012).

\section{Decision-making (alone or jointly)}

Different decisions were labelled according to who took the decision. Any decision that was taken by the respondent herself was labelled ' 2 '. A decision that was jointly taken by the respondent and her husband or by the respondent and another person was labelled ' 1 '. Finally, other possible options mentioned earlier were labelled ' 0 '.

\section{Agreeing with justifications for wife beating}

Agreement with any of five reasons was coded (1) while rejection of wife beating for any of the five reasons was coded (2). Others were coded (0).

This type of computation is consistent with that used by Kishor and Gupta (2004) and Kishor and Subaiya (2008).

\section{B. Independent variables}

Women's empowerment covariates include variables at household and community levels. These variables include age in years, children ever born, regular exposure to media, employment for cash, age at first marriage, residence in urban area, spousal age difference 
and household wealth. Some of these variables are considered potential sources of empowerment, specifically age, media exposure, educational level and employment for cash. Other variables are conceptualized as aspects of a setting for empowerment (nuclear family and urban residence, wealth, age at first marriage and spousal age difference) (Kishor, 2000; Kishor and Subaiya, 2008).

Age: women's age is positively associated with her level of empowerment as believed by a majority of religions around the world especially when women's empowerment is measured using indicators that measure household decision-making. Nonetheless, when empowerment is measured using indicators of attitudes towards gender equality, it is not clear whether empowerment is positively associated with age.

Number of children ever born: More respect is accorded to women who have children. Nonetheless, it is hard to predict the direction of causality between the number of children ever born and attitudes to gender roles.

Education and media exposure: Education and media exposure equip women with information and means that can allow them to effectively adapt to the changing modern world thus increasing their level of empowerment. People with higher education are exposed to new ideas and alternative behaviours and gender norms and roles. Thus education is a critical source of empowerment. For example, women with higher education are less likely to accept wife beating for any reason and are more likely to believe that it is a woman's right to refuse sex with her husband.

Employment for cash: Earning cash is more likely to increase women's bargaining powers within households. This gives women a sense of personal achievement and it also helps in creating awareness about the fact that they are like men and can provide financial support for their families. In addition, off-farm professional occupations potentially empower women through financial autonomy and alternative sources of identity and social exposure to new structures of power free of kin networks (Kishor and Subaiya, 2008).

Media exposure: Access to media (watching television on a regular basis, reading newspapers and frequency of listening to the radio) have the same direction of causality like education as they too expose women to new ideas and gender roles and norms. This postulates that women with frequent exposure to media have a low likelihood of accepting that women being beaten is justified for any reason and they are more likely to accept that it is a woman's right to refuse sex with her husband when necessary.

Age at first marriage: A younger age at first marriage is negatively associated with women's empowerment as it puts to an end a woman's chance to have access to sources of empowerment like education (Kishor and Subaiya, 2008). In addition, a younger age at first marriage is associated a high probability of a woman agreeing that wife beating is justified for any reason.

Urban residence: In cities there are people from different backgrounds doing a variety of offfarm jobs with a variety of services including easy access to education and regular media exposure. Hence, as compared to rural women, urban women are more likely to reject wife 
beating for any reason. These women are of the view that women have the right to refuse sex with their husbands.

Wealth: Wealth and gender equality do not easily go hand in hand. On the one hand, household wealth is a source of empowerment as it brings education, exposure to media and exposure to networks of intellectuals, but on the other hand wealthier households are more likely to be strongly attached to patriarchal gender norms.

Husband's education: A husband's education level, especially secondary education and above, is likely to have a positive association with women's empowerment.

\section{Empirical results}

The results of a linear regression analysis between women's empowerment (cumulative empowerment index, decision-making index and self-esteem index) and its covariates are presented in Table 1 . The results of a multinomial logistic regression analysis between women's empowerment indicators (taking decisions alone or jointly), attitudes towards justifications for wife beating) and women's empowerment covariates are summarized in Tables 2, 3 and 4.

Insert Table 1 about here

\subsection{Relationship between women's empowerment and its covariates}

Table 1 depicts the relationship between women's empowerment and its covariates. In column 1 it gives the association between the cumulative empowerment index and its covariates. It is apparent from this column that there is a significant positive correlation between women's empowerment and some of its covariates such as age, number of children ever born, education, employment for cash, exposure to media and wealth. Younger women in their twenties are less likely to be empowered (0.0274) as compared to older women (0.0339). The results show that women with more children (5 and above) are more likely to be empowered (0.160) than women with less children ( 1 or 2 ) whose coefficient is only 0.114. The results also indicate that women with higher education seem to be more empowered (0.171) than those with primary education (0.030). Similarly, employment for cash and media exposure appear to be positively associated with the cumulative empowerment index (see Table 1, column 1). Women in wealthier families are more likely to be empowered (0.0525) than those from poor families (0.0190).

In the same way, the same direction of causality is observed with the decision-making index (see results in Table 1, column 2). These results match those observed in previous studies. Women's empowerment was found to be positively associated with education levels, age, household wealth (income) and employment status (such as in Sultana and Hossen, 2013). Likewise, Khan and Noreen, (2012) found that women's empowerment was mainly determined by age, husband's education, assets inherited from the father, number of children alive and the amount of microfinance. 
On the contrary, living in a rural area and getting married at a younger age were found to be negatively associated with both the cumulative empowerment and decision-making indices. Moreover, the results revealed a significant positive association between self-esteem and variables such as education, wealth and age of the respondent (see Table 1, column 3). Women with higher education seem to have higher levels of self-esteem (0.268) than those with primary education (0.0527). Women from wealthier families appear to have higher selfesteem (0.080) than those from poor families (0.020). However, residence (rural) and age at first marriage were found to be negatively associated with self-esteem (see Table 1, column 3).

These results are in agreement with those obtained by Kishor and Subaiya (2008) who found that women in urban areas were more likely to reject wife beating than women in rural areas and younger age at first marriage was associated with a high likelihood of accepting justifications for wife beating.

Insert Table 2 about here

\subsection{Determinants of household decision-making}

Tables 2 and 3 present odds ratios (using a multinomial logistic regression) for respondents' decision-making (jointly and alone) on five household decisions--what to do with respondent's earnings, respondent's healthcare, large household purchases, visits to family or relatives and what to do with money that the husband earns. Women in their twenties appear to have high odds in favour of taking decisions alone on all the five aspects as compared to older women. Table 2 shows that women with more children ( 5 and above) are more likely to take the five household decisions alone as compared to women with less children .The results also show that women with higher education have higher chances of taking decisions alone compared to those with primary education. Media exposure was found to increase a respondent's likelihood of taking decisions alone for all the five questions. Likewise, women from wealthier families had higher odds when it comes to taking decisions alone as compared to those from poor families. Surprisingly, women with low age at first marriage (18-24 years) were found to be more likely to take decisions alone compared to those with higher age at first marriage. However, employment for cash influenced taking decisions alone for some decisions while residence had no influence on decision-making alone.

\section{Insert Table 3 about here}

As shown in Table 3, the odds of joint decision-making for four of the five questions were high among younger women as compared to older women. Surprisingly, older women were more likely to take a decision jointly on their healthcare as compared to younger women. Joint decision-making was found to be an increasing function of the women's number of children. Employment for cash seems to increase the odds of joint decision-making on all five household decisions. However, variables such as education, wealth, media exposure and residence appear to have an influence on only a few of the decisions. For example, residence 
(rural areas) reduces a respondent's likelihood to jointly decide about what to do with her earnings and about large household purchases.

Insert Table 4 about here

\subsection{Determinants of respondents' attitudes towards justifications for wife beating}

Table 4 illustrates the odds ratios about respondents' attitudes on justifications for wife beating. Women with higher education were less likely to agree with wife beating (for all five reasons) than those with primary education. Women from wealthier families were less likely to agree with wife beating for all five reasons than those from poor families. Residing in rural areas was found to increase the odds for agreeing with wife beating for all five reasons. However, variables such as age, children ever born, media exposure and paid work influenced some of the reasons. Unlike our expectations, age at first marriage had no influence on attitudes towards wife beating.

\section{Discussion of the results}

The study was designed to measure women's empowerment in Rwanda using indicators of household decision-making and self-esteem. Kabeer (2001) and Kishor (2008) conceptualize empowerment in terms of agency, resources and achievements.

It was hypothesized that variables of sources of empowerment (education, employment for cash, media exposure and wealth) have a positive association with women's empowerment while variables of setting for empowerment (residence, age, children, age at first marriage) have either a positive or a negative influence on women's empowerment. For example, younger age at first marriage was expected to be negatively associated with women's empowerment while a higher age at first marriage tended to be positively associated with women's empowerment.

The results from our study show that older women are more likely to be empowered (0.074) than younger women (0.039). Household decision-making was found to be high among older women as compared to young women (see Table 1). Similarly, the results showed that old respondents appeared to have higher self-esteem (0.0448) as compared to younger women (0.0225). A possible explanation for these results is that marriage and child bearing are highly valued by a majority of the societies and this allows women to gain respect, rights and freedom. These results are consistent with those obtained by Kishor and Subaiya (2008) in a cross-country women's empowerment comparison using the DHS data.

Women with more children ( 5 and above) were found to be more empowered than women with less children (1 or 2) (see results in Table 1). Likewise, household decision-making appears to be higher among women with more children than among those with less children. Surprisingly, no relationship was found between self-esteem and the number of children ever born. A possible explanation for the positive relationship between women's empowerment, decision-making and child bearing is that more empowerment and status are accorded to women with children and this goes hand in hand with a woman's age. 
The findings also reveal that women's educational levels were positively associated with their level of empowerment. Women with higher education were more empowered than those with primary education. Similarly, women with higher education were found to have higher decision-making abilities than those with primary education; this is consistent with the findings of Sado et al. (2014). Women with higher education seem to have higher selfesteem than women with primary education (see Table1) and a possible explanation for this is that higher education exposes women to new ideas and alternative gender norms and behaviours thus having a gender-egalitarian view of the world. These results are in agreement with those obtained by Mahmud et al. (2012). Employment for cash had a positive association with both the cumulative empowerment index (0.0202) and the decision-making index (0.0332). However, employment for cash had no association with the self-esteem index.

Regular media exposure was positively associated with both the cumulative empowerment index and the decision-making index. This can be attributed to the fact that the media exposes women to the world outside their homes including to new ideas and non-traditional roles for women. These results are consistent with Mahmud et al.'s, (2012) findings. Unlike our expectations, no relationship was found between media exposure and women's empowerment and self-esteem. Residence (rural area) was negatively associated with the cumulative empowerment index and the self-esteem index but it was unrelated to the household decision-making index (see Table 1).

Age at first marriage had a significant negative relationship with the cumulative empowerment and decision-making indices (see Table 1). One possible explanation for this is that an early age at first marriage limits the access that a woman has to education. She also has less time dedicated to her development and maturity without the interference of marriage and the responsibilities of raising children. Moreover, being young, she is less likely to be accorded much power and independence in her parents' home. These findings are similar to those by Kishor and Subaiya (2008). However, unlike them our study did not find any association between self-esteem and the age at first marriage.

Wealth was found to be positively associated with the cumulative empowerment and selfesteem indices. Women from wealthier families seemed to be more empowered and had higher self-esteem than those from poor families. However, wealth was positively associated with household decision-making for only the rich but was unrelated with poorest, poorer and middle income families (see Table 1).

Younger women (20-29 years) were less likely to take decisions alone and jointly as compared to those in the 30-39 years age bracket, but women in the 40-49 years age group were less likely to take four or five decisions alone and jointly as compared to women in their twenties (see Table 1). Surprisingly, older women were more likely to take decisions jointly about their healthcare than younger women (see Tables 2 and 3). These results are in line with those of previous studies such as those by Mahmud et al. (2012) whose findings reveal that young and older women were reported to have lower decision-making powers while women in their mid-twenties had high decision-making powers. This phenomenon can be explained by the fact that there are chances that young women live in extended families 
and old women are no longer involved in decision-making as most of them rely on their adult sons.

Decision making alone and jointly increases with the number of children for all five decisions (see Table 2 and 3). These results further support Kishor and Subaiya's (2008) findings who state that the proportion of women who take decisions alone or jointly increases with the number children.

As a potential source of empowerment, education is positively associated with household decision-making, notably with decision-making alone. The odds of women's participation in decision-making increase with the level of education but with variations in terms of type of participation and decisions. The results show that compared to primary education, higher education is positively associated with decision-making alone for all five decisions (see Table 2 and 3). However, the proportion of women with higher education who take decisions jointly is higher for only three decisions (what to do with respondent's earnings, respondent's healthcare and large household purchases). These results are in agreement with El-Halawany's (2009) findings which show that education is strongly associated with women's autonomy, empowerment and gender equality through their participation in household decision-making.

Employment for cash affected decision-making alone (positive association) for only three decisions (what to do with respondent's earnings, large household purchases and visits to family or relatives) (see Table 2). Unlike our expectations, employment for cash affected decision-making jointly for four decisions (what to do with respondent's earnings, respondent's healthcare, large household purchases and visits to family or relatives) (Table 3). These results match those observed in earlier studies such as those by Mahmud and Tasmeen (2014) who argue that the likelihood of spending one's own income on clothes, healthcare, investments in major assets and having a bank account were higher among women with formal employment outside the family than in other categories. Similarly, Malhotra et al., (2009) found that innovations promoted women's empowerment through increased freedom, having a say in household decision-making, control over household resources and confidence to challenges gender inequalities.

The odds in favour of taking a decision alone increased with the level of media exposure for all five decisions. However, exposure to media affected joint decision-making for only two decisions (respondent's healthcare and visits to family or relatives). These findings further support Kishor and Subaiya's findings (2008) that women with regular exposure to the media tended to have positive attitudes towards gender equality than those who are not exposed to the media. They further argue that women who lived in communities that favour women's exposure to the media or allowed them to benefit from social development levels appeared to have a higher likelihood of taking decisions alone and low likelihood of taking decisions jointly.

Age at first marriage had a significant negative association with decision-making alone for all five questions (see Table 2) while it had significant negative association with decisionmaking jointly for only two decisions (what to do with respondent's earnings and large household purchases) (see Table 3). Contrary to our expectations, residence (rural area) 
increased the odds in favour of taking decisions alone on what to do with husband's earnings (see Table 2) while residence (rural area) reduced the likelihood of taking a decision jointly for only two decisions (what to do with respondent's earnings and large household purchases) (see Table 3).

Wealth has a significant positive relationship with taking decisions alone for all five questions with women from wealthier families having higher chances of taking decisions alone compared to those from poor families (see Table 2). Wealth had a statistically negative association with decision-making jointly for only two decisions (large household purchases and visits to family or relatives). These results are in accord with recent studies indicating that women from wealthier households are less likely to have a say in household decisionmaking and that they tend to have the view that there voice is not relatively worthwhile but there is a high likelihood for them to have access to cash to spend (Mahmud et al., 2012).

Older women were found to be less likely to agree with four of the five justifications for wife beating. Education was negatively associated with agreeing with justifications for wife beating for all five reasons (see Table 4). Women with higher education were less likely to agree with wife beating for any of the five reasons as compared to those with lower education levels (primary education). These findings are in agreement with Kishor and Subaiya's (2008) findings which show that the higher the education level, the lower the likelihood of a woman agreeing that wife beating was justified for any reason and the higher the likelihood of her agreeing with the fact that it is a woman's right to refuse sex with her husband.

Women with paid work are less likely to agree with justifications for wife beating for three of the five reasons (see Table 4). Women with regular exposure to media are less likely to agree with wife beating for two of the five reasons. Women residing in rural areas were found to be more likely to agree with justifications for wife beating for all the five reasons. Wealth reduced the odds in favour of saying yes to justifications for wife beating for all the five reasons. Women with from wealthier families were less likely to agree with justifications for wife beating for all five reasons as compared to women from poor families.

Table 4 illustrates the odds ratios about respondents' attitudes towards justifications for wife beating. Women with higher education are less likely to agree with wife beating (for all five reasons) than those with primary education (see Table 4). Women from wealthier families are also less likely to agree with wife beating for all five reasons than those from poor families. Residing in rural areas was found to increase the odds in favour of justifications for wife beating for all five reasons. However, variables such as age, children ever born, media exposure and paid work appear to influence some of the reasons. Unlike our expectations, age at first marriage had no influence on attitudes towards wife beating.

\section{Conclusions}

The most obvious finding of this study is that education, age of the respondent, media exposure, employment for cash and wealth have a positive relationship with women's empowerment. Our study also found that education, wealth, age and the number of children have high explanatory powers for women's empowerment as compared to the other 
variables. Taken together, the findings suggest that women's empowerment can be achieved through providing education, labour force participation, media exposure, shifting negative traditional cultural norms and by focusing on integrated development.

The main weakness of this study is the paucity of data on all indicators of women's empowerment (only data on household decision-making and attitudes towards wife beating were available) and some of the covariates that were used in previous studies. Another weakness is that the results might have been affected by missing values on the data on measuring women's empowerment. As society is evolving fast through education, technology, urbanization and globalization this requires continuous improvements in survey structures; there is also a need to collect data on women's empowerment indicators that have not been taken into account in previous surveys.

Further studies need be carried out on the uncovered aspects of women's empowerment especially the relationship between women's empowerment and variables such as fertility, healthcare, contraceptive use and microfinance. Women's autonomy and their determination to participate in the labour force, as well as their contribution to economic growth and wellbeing also need to be considered.

\section{References}

Abadian, S. (1996). Women's autonomy and its impact on fertility, World Development, 24(12), 1793-1809.

Al Riyami, A., M. Afifi, and R.M. Mabry (2004). Women's autonomy, education and employment in Oman and their influence on contraceptive use, Reproductive Health Matters, 12(23), 144-154.

Ali, D.A., K. Deininger, and M. Goldstein (2014). Environmental and gender impacts of land tenure regularisation in Africa: Pilot evidence from Rwanda, Journal of Development Economics, 110, 262-275.

Allendorf, K. (2007). Do women's land rights promote empowerment and child health in Nepal? World Development, 35(11), 1975-1988.

Allsopp, M.S. and A. Tallontire (2014). Pathways to empowerment? Dynamics of women's participation in global value chains, Journal of Cleaner Production, 107, 114-121.

Alsop, R. and N. Heinsohn (2005). Measuring empowerment in practice: Structuring, analysing and framing indicators, World Bank Policy Research Working Paper 3510.

Bloom, S.S., D. Wypij, and M.D. Gupta (2001). Dimensions of women's autonomy and the influence of maternal health care utilization in a north Indian city, Demography, 38(1), 67-78.

El-Halawany, H.S. (2009). Higher education and some upper Egyptian women's negotiation of self-autonomy at work and home, Research in Comparative and International Education, 4(4), 423-436.

Faridi, M.Z., I.S. Chaudhry, and M. Anwar (2009). The social-economic and demographic determinants of women's work participation in Pakistan: Evidence from Bahawalpur district, MPRA Paper 22831. 
Fotso, J.C., A.C. Ezeh, and H. Essendi (2009). Maternal health in resource-poor urban settings: How does women's autonomy influence the utilization of obstetric care services? Reproductive Health, June 16, Jun 16;6:9. doi: 10.1186/1742-4755-6-9.

Ganle, J.K., K. Afriyie, and A.O. Segbefia (2015). Microcredit: Empowerment and disempowerment of rural women in Ghana, World Development, 66, 335-345.

Ghuman, S.J., H.J. Lee, and H.L. Smith (2004). Measurement of women's autonomy according to women and their husbands: Results from five Asian countries, Social Science Research, 35, 1-28.

Goldman, M.J. and J.S. Little (2015). Innovative grassroots NGOs and the complex processes of women's empowerment: An empirical investigation from northern Tanzania, World Development, 66, 762-777.

Golla, A.M., A. Malhotra, P. Nanda, and R. Mehra (2011). Understanding and measuring women's economic empowerment: Definitions, framework and indicators. International Center for Research on Women (ICRW).

Hashemi, S.M., S.R. Schuler, and A.P. Riley (1996). Rural credit programs and women's empowerment in rural Bangladesh, World Development, 24(4), 635-653.

Kabeer, N. (1999a). Resources, agency, achievements: Reflections on the measurement of women's empowerment, Development and Change, 30, 435-464.

Kabeer, N. (1999b). The conditions and consequences of choice: Reflections on the measurement of women's empowerment, UNRISD Discussion Paper 108.

Kabeer, N. (2001). Conflicts over credit: Re-evaluating the empowerment potential of loans to women in rural Bangladesh, World Development, 29(1), 63-84.

Kabeer, N. (2005). Gender equality and women's empowerment: A critical analysis of the third millennium development goal 1, Gender and Development, 13(1), 13-24.

Kar, S.B., C.A. Pascual, and K.L. Chickering (1999). Empowerment of women for health promotion: A meta- analysis, Social Science and Medicine, 49, 1431-1460.

Khan, A. and S. Noreen (2012). Microfinance and women's empowerment: A case study of Bahawalpur district (Pakistan), African Journal of Business Management, 6(12), 45144521.

Kishor, S. and K. Gupta (2004). Women's empowerment in India and its states: Evidence from the NFHS, Economic and Political Weekly, 39(7), 694-712.

Kishor, S. and L. Subaiya (2008). Understanding women's empowerment: A comparative analysis of Demographic and Health Survey (DHS) data. USAID.

Larsen, U. and M. Hollos (2003). Women's empowerment and fertility decline among the pare of Kilimanjaro region, northern Tanzania, Social Science and Medicine, 57, 10991115.

Lee-Rife, S.M. (2010). Women's empowerment and reproductive experiences over the life course, Social Science and Medicine, 71, 634-642.

Mahmud, S. and S. Tasneem (2014). Measuring' empowerment' using quantitative household survey data, Women's Studies International Forum, 45, 90-97.

Mahmud, S., N.M. Shah, and S. Becker (2012). Measuring women's empowerment in rural Bangladesh, World Development, 40(3), 610-619. 
Malhotra, A. and M. Mather (1997). Do schooling and work empower women in developing countries? Gender and domestic decisions in Sri Lanka, Sociological Forum, 12(4), 559-630.

Malhotra, A., J. Schulte, P. Patel, and P. Petesch (2009). Innovations for Women's empowerment and gender equality. International Center for Research on Women (ICRW).

Mukashema, I. and R. Sapsford (2013), Marital Conflicts in Rwanda: Points of View of Rwandan Psycho-socio-medical Professionals. Procedia-Social and Behavioral Sciences, 82:149-68.

Naqvi, Z.F. and L. Shahnaz (2002). How do women decide to work in Pakistan? Pakistan Development Review, 41(4), 495-513.

NISR. (2010). Demographic and Health Survey (DHS). Kigali: National Institute of Statistics for Rwanda.

NISR. (2010). Integrated Household Living Conditions (EICV3): Gender thematic report. National Institute of Statistics for Rwanda.

NISR. (2013). Statistical Year Book. Kigali: National Institute of Statistics for Rwanda.

Patrikar, S.R., D.R. Basannar, and M.S. Sharma (2014). Women empowerment and use of contraception, Medical Journal Armed Forces INDIA, 70, 253-256.

Rowland, J. (1997). Questioning empowerment, Oxford: Oxfam

Sado, L., A. Spaho, and D.R. Hotchkiss (2014). The influence of women's empowerment on maternal health care utilization: Evidence from Albania, Social Science and Medicine, 114, 169-177.

Samman, E. and M.E. Santos (2009). Agency and empowerment: A review of concepts, indicators and empirical evidence, Oxford Poverty and Human Development Initiative.

Schuler, S.R., S.M. Hashemi, A.P. Riley, and S. Akther (1996). Credit programs, patriarchy and men's violence against women in rural Bangladesh, Social Science and Medicine, 43(12), 1729-1742.

Schuler, S.R., S.M. Hashemi, and A.P. Riley (1997). The influence of women's changing roles and status in Bangladesh's fertility transition: Evidence from a study on credit programs and contraceptive use, World Development, 25(4), 563-575.

Sultana, A. and S. Hossen (2013). Role of employment in women empowerment: Evidence from Khulna city of Bangladesh, International Journal of Social Science and Interdisciplinary Research, 2(7), 117-125.

Trommlerova, S.K., S. Klasen, and O. Lebmann (2015). Determinants of empowerment in capability-based poverty approach: Evidence from the Gambia, World Development, 66, 1-15.

Upadhyay, U.D. and D. Karasek (2012). Women's empowerment and the ideal family size: An examination of DHS empowerment measures in sub-Saharan Africa, International Perspectives on Sexual and Reproductive Health, 38(2), 78-89.

Upadhyay, U.D., J.D. Gipson, M. Withers, S. Lewis, E.J. Ciaraldi, A. Fraser, M.J. Huchko, and N. Prata (2014). Women empowerment and fertility: A review of literature, Social Science and Medicine, 115, 110-120.

World Bank (2012). Gender Inequality and Development. World Development Report 2012. The World Bank. 


\begin{tabular}{|c|c|c|c|}
\hline & $\begin{array}{l}\text { Cumulative Empowerment } \\
\text { Index }\end{array}$ & $\begin{array}{l}\text { Decision-making } \\
\text { Index }\end{array}$ & $\begin{array}{l}\text { Self-esteem } \\
\text { Index }\end{array}$ \\
\hline \multicolumn{4}{|l|}{ Age groups: } \\
\hline \multicolumn{4}{|l|}{ 15-19(Ref.) } \\
\hline \multirow[t]{2}{*}{$20-29$} & $0.0274 * * *$ & $0.0525 * * *$ & 0.00225 \\
\hline & (5.22) & (9.62) & $(0.26)$ \\
\hline \multirow[t]{2}{*}{ 30-39 } & $0.0455^{* * *}$ & $0.0591 * * *$ & $0.0320 * *$ \\
\hline & $(6.45)$ & $(8.04)$ & $(2.77)$ \\
\hline \multirow[t]{2}{*}{$40-49$} & $0.0339 * * *$ & $0.0230 *$ & $0.0448 * *$ \\
\hline & $(3.58)$ & $(2.33)$ & $(2.89)$ \\
\hline \multicolumn{4}{|l|}{ Children categories: } \\
\hline \multicolumn{4}{|l|}{ None (Ref.) } \\
\hline \multirow[t]{2}{*}{1 or 2} & $0.114 * * *$ & $0.223^{* * *}$ & 0.00424 \\
\hline & $(22.15)$ & $(41.77)$ & $(0.50)$ \\
\hline \multirow[t]{2}{*}{3 or 4} & $0.134^{* * *}$ & $0.276^{* * *}$ & -0.00743 \\
\hline & $(21.43)$ & $(42.32)$ & $(-0.72)$ \\
\hline \multirow[t]{2}{*}{5 and above } & $0.160 * * *$ & $0.332 * * *$ & -0.0116 \\
\hline & $(21.72)$ & $(43.25)$ & $(-0.96)$ \\
\hline \multicolumn{4}{|l|}{ Education: } \\
\hline \multicolumn{4}{|l|}{ None (Ref.) } \\
\hline \multirow[t]{2}{*}{ Primary } & $0.0365 * * *$ & $0.0203^{* * *}$ & $0.0527 * * *$ \\
\hline & (7.34) & (3.92) & $(6.47)$ \\
\hline \multirow[t]{2}{*}{ Secondary } & $0.104 * * *$ & $0.0193 * *$ & $0.188 * * *$ \\
\hline & $(15.18)$ & $(2.71)$ & $(16.83)$ \\
\hline \multirow[t]{2}{*}{ Higher } & $0.171^{* * *}$ & $0.0730 * * *$ & $0.268 * * *$ \\
\hline & $(12.19)$ & $(5.01)$ & $(11.71)$ \\
\hline \multicolumn{4}{|l|}{ Employment for cash: } \\
\hline \multicolumn{4}{|l|}{ No paid work (Ref.) } \\
\hline \multirow[t]{2}{*}{ Paid work } & $0.0202 * * *$ & $0.0332 * * *$ & 0.00734 \\
\hline & $(5.26)$ & $(8.28)$ & $(1.17)$ \\
\hline \multicolumn{4}{|l|}{ Media exposure: } \\
\hline \multicolumn{4}{|l|}{$\begin{array}{l}\text { No regular media exposure } \\
\text { (Ref.) }\end{array}$} \\
\hline \multirow[t]{2}{*}{ Regular media exposure } & $0.0159 * * *$ & $0.0237 * * *$ & 0.00820 \\
\hline & $(4.54)$ & $(6.47)$ & $(1.43)$ \\
\hline \multicolumn{4}{|l|}{ Residence: } \\
\hline \multicolumn{4}{|l|}{ Urban (Ref.) } \\
\hline \multirow[t]{2}{*}{ Rural } & $-0.0230 * * *$ & -0.00642 & $-0.0396 * * *$ \\
\hline & $(-4.36)$ & $(-1.17)$ & $(-4.59)$ \\
\hline \multicolumn{4}{|l|}{ Age at first marriage: } \\
\hline \multicolumn{4}{|l|}{ Less than 18 years(Ref.) } \\
\hline \multirow[t]{2}{*}{$18-24$ years } & $-0.0238 * *$ & $-0.0473 * * *$ & -0.000 \\
\hline & $(-3.10)$ & $(-5.91)$ & $(-0.02)$ \\
\hline
\end{tabular}




\begin{tabular}{|l|l|l|l|}
\hline 25 years and above & $-0.0281^{* *}$ & $-0.0578^{* * *}$ & 0.0014 \\
\hline & $(-2.79)$ & $(-5.49)$ & $(0.09)$ \\
\hline Poorest (Ref.): & & & \\
\hline Poorer & $0.0190^{* * *}$ & 0.0103 & $0.0278^{* *}$ \\
\hline & $(3.52)$ & $(1.82)$ & $(3.14)$ \\
\hline Middle & $0.0295^{* * *}$ & 0.0102 & $0.0488^{* * *}$ \\
\hline & $(5.37)$ & $(1.78)$ & $(5.43)$ \\
\hline Richer & $0.0381^{* * *}$ & $0.0194^{* * *}$ & $0.0568^{* * *}$ \\
\hline & $(6.77)$ & $(3.31)$ & $(6.17)$ \\
\hline Richest & $0.0525^{* * *}$ & $0.0250^{* * *}$ & $0.0800^{* * *}$ \\
\hline & $(8.44)$ & $(3.86)$ & $(7.86)$ \\
\hline Cons & $0.265^{* * *}$ & $-0.0639^{* * *}$ & $0.593^{* * *}$ \\
\hline & $(31.02)$ & $(-7.20)$ & $(42.48)$ \\
\hline $\mathrm{N}$ & 13,671 & 13,671 & 13,671 \\
\hline
\end{tabular}

Note: t-statistics in parentheses ${ }^{*} \mathrm{p}<0.05,{ }^{* *} \mathrm{p}<0.01,{ }^{* * *} \mathrm{p}<0.001$. 


\begin{tabular}{|c|c|c|c|c|c|}
\hline & $\begin{array}{l}\text { What to do } \\
\text { with } \\
\text { respondent's } \\
\text { earnings }\end{array}$ & $\begin{array}{l}\text { Respondent's } \\
\text { healthcare }\end{array}$ & $\begin{array}{l}\text { Large } \\
\text { household } \\
\text { purchases }\end{array}$ & $\begin{array}{l}\text { Visits to } \\
\text { family } \\
\text { relatives }\end{array}$ & $\begin{array}{l}\text { What to do } \\
\text { with } \\
\text { husband's } \\
\text { earnings }\end{array}$ \\
\hline \multicolumn{6}{|l|}{ Age groups: } \\
\hline \multicolumn{6}{|l|}{$15-19$} \\
\hline \multirow[t]{2}{*}{$20-29$} & $1.902 * * *$ & $1.919 * * *$ & $2.039 * * *$ & $2.117 * * *$ & $1.985^{* * *}$ \\
\hline & $(9.81)$ & $(12.42)$ & $(13.56)$ & $(14.20)$ & $(13.58)$ \\
\hline \multirow[t]{2}{*}{$30-39$} & $1.741^{* * *}$ & $1.805 * * *$ & $2.020 * * *$ & $2.039 * * *$ & $1.850 * * *$ \\
\hline & $(8.60)$ & $(10.94)$ & $(12.65)$ & $(12.79)$ & $(11.87)$ \\
\hline \multirow[t]{2}{*}{$40-49$} & $1.304 * * *$ & $1.480 * * *$ & $1.678 * * *$ & $1.482 * * *$ & $1.376 * * *$ \\
\hline & $(5.96)$ & $(8.08)$ & $(9.53)$ & $(8.33)$ & $(7.98)$ \\
\hline \multicolumn{6}{|l|}{ Children categories: } \\
\hline \multicolumn{6}{|l|}{ None } \\
\hline \multirow[t]{2}{*}{1 or 2} & $2.318 * * *$ & $2.405 * * *$ & $2.354 * * *$ & $2.524 * * *$ & $2.412 * * *$ \\
\hline & $(23.88)$ & $(28.28)$ & $(29.94)$ & $(32.17)$ & $(30.50)$ \\
\hline \multirow[t]{2}{*}{3 or 4} & $2.588^{* * *}$ & $2.822 * * *$ & $2.556 * * *$ & $2.839 * * *$ & $2.628 * * *$ \\
\hline & $(24.24)$ & $(29.22)$ & $(28.69)$ & $(31.30)$ & (29.30) \\
\hline \multirow[t]{2}{*}{5 and above } & $2.806 * * *$ & $3.305^{* * *}$ & $2.979 * * *$ & $3.494 * * *$ & $3.101^{* * *}$ \\
\hline & $(23.68)$ & $(30.22)$ & $(29.49)$ & $(33.28)$ & $(30.47)$ \\
\hline \multicolumn{6}{|l|}{ Education: } \\
\hline \multicolumn{6}{|l|}{ No education } \\
\hline \multirow[t]{2}{*}{ Primary } & 0.0980 & $0.208 * * *$ & $0.133 *$ & $0.151 *$ & $0.158 * *$ \\
\hline & $(1.51)$ & $(3.33)$ & $(2.25)$ & $(2.45)$ & $(2.70)$ \\
\hline \multirow[t]{2}{*}{ Secondary } & 0.149 & 0.0228 & 0.0248 & 0.0289 & 0.0267 \\
\hline & $(1.45)$ & $(0.23)$ & $(0.27)$ & $(0.30)$ & $(0.29)$ \\
\hline \multirow[t]{2}{*}{ Higher } & $0.904 * * *$ & $0.516^{* *}$ & $0.733^{* * *}$ & $0.707 * * *$ & $0.613 * * *$ \\
\hline & $(4.56)$ & $(2.60)$ & $(4.00)$ & $(3.73)$ & $(3.38)$ \\
\hline \multicolumn{6}{|l|}{ Employment for cash: } \\
\hline \multicolumn{6}{|l|}{ No paid work } \\
\hline Paid work & $1.186 * * *$ & -0.0383 & $0.127 *$ & $0.190 * * *$ & 0.0558 \\
\hline \multicolumn{6}{|l|}{ Exposure to media } \\
\hline \multicolumn{6}{|l|}{ No media exposure } \\
\hline \multirow[t]{2}{*}{ Low media exposure } & $0.359 * * *$ & $0.365 * * *$ & $0.430 * * *$ & $0.463 * * *$ & $0.471 * * *$ \\
\hline & $(6.33)$ & $(6.75)$ & $(8.41)$ & $(8.71)$ & $(9.26)$ \\
\hline \multirow[t]{2}{*}{ High media exposure: } & $0.344^{*}$ & $0.442 * *$ & 0.273 & $0.362 *$ & $0.464 * *$ \\
\hline & $(2.20)$ & $(2.89)$ & $(1.89)$ & $(2.43)$ & $(3.25)$ \\
\hline \multirow[t]{2}{*}{ Rural } & 0.138 & 0.0805 & 0.0677 & 0.0465 & $0.192^{* *}$ \\
\hline & $(1.73)$ & $(1.06)$ & $(0.95)$ & $(0.63)$ & $(2.71)$ \\
\hline \multicolumn{6}{|l|}{ Age at first marriage: } \\
\hline \multicolumn{6}{|l|}{ Less than 18} \\
\hline \multirow[t]{2}{*}{ 18-24 years } & $-0.246^{* *}$ & $-0.454 * * *$ & $-0.369 * * *$ & $\begin{array}{c}- \\
0.502^{* * *}\end{array}$ & $-0.439 * * *$ \\
\hline & $(-2.61)$ & $(-4.92)$ & $(-4.25)$ & $(-5.43)$ & $(-5.10)$ \\
\hline
\end{tabular}




\begin{tabular}{|l|c|c|c|c|c|}
\hline 25 and above & $-0.311^{*}$ & $-0.693^{* * *}$ & $-0.509^{* * *}$ & $\begin{array}{c}- \\
0.607^{* * *}\end{array}$ & $-0.575^{* * *}$ \\
\hline & $(-2.45)$ & $(-5.65)$ & $(-4.44)$ & $(-5.03)$ & $(-5.05)$ \\
\hline Poorest: & & & & & \\
\hline Poorer & $0.250^{* *}$ & $0.289^{* * *}$ & $0.140^{*}$ & $0.259^{* * *}$ & $0.193^{* *}$ \\
\hline Middle & $(3.21)$ & $(3.89)$ & $(1.99)$ & $(3.54)$ & $(2.77)$ \\
\hline & $0.311^{* * *}$ & $0.291^{* * *}$ & $0.224^{* *}$ & $0.324^{* * *}$ & $0.244^{* * *}$ \\
\hline Richer & $(3.90)$ & $(3.80)$ & $(3.11)$ & $(4.31)$ & $(3.41)$ \\
\hline & $0.404^{* * *}$ & $0.560^{* * *}$ & $0.379^{* * *}$ & $0.527 * * *$ & $0.440^{* * *}$ \\
\hline Richest & $(4.97)$ & $(7.13)$ & $(5.13)$ & $(6.81)$ & $(5.98)$ \\
\hline & $0.473^{* * *}$ & $0.542^{* * *}$ & $0.442^{* * *}$ & $0.500^{* * *}$ & $0.493^{* * *}$ \\
\hline Cons & $(5.09)$ & $(6.07)$ & $(5.26)$ & $(5.71)$ & $(5.90)$ \\
\hline & $-6.478^{* * *}$ & $-5.230^{* * *}$ & $-5.141^{* * *}$ & - & $-5.242^{* * * *}$ \\
\hline $\mathrm{N}$ & $(-29.19)$ & $(-28.86)$ & $(-29.33)$ & $(-29.88)$ & $(-30.49)$ \\
\hline
\end{tabular}

Note: t-statistics in parentheses ${ }^{*} \mathrm{p}<0.05,{ }^{* *} \mathrm{p}<0.01,{ }^{* * *} \mathrm{p}<0.001$. 


\begin{tabular}{|c|c|c|c|c|c|}
\hline & $\begin{array}{l}\text { What to do } \\
\text { with } \\
\text { respondent } \\
\text { earnings }\end{array}$ & $\begin{array}{l}\text { Respondent's } \\
\text { healthcare }\end{array}$ & $\begin{array}{l}\text { Large } \\
\text { household } \\
\text { purchases }\end{array}$ & $\begin{array}{l}\text { Visits to } \\
\text { family or } \\
\text { relatives }\end{array}$ & $\begin{array}{l}\text { What to do } \\
\text { with } \\
\text { husband's } \\
\text { earnings }\end{array}$ \\
\hline \multicolumn{6}{|l|}{ Age groups: } \\
\hline \multicolumn{6}{|l|}{$15-19$} \\
\hline \multirow{2}{*}{$20-29$} & $2.402 * * *$ & $2.399 * * *$ & $2.019 * * *$ & $2.090 * * *$ & $2.193 * *$ \\
\hline & (4.03) & (5.66) & (3.31) & (5.25) & $(2.95)$ \\
\hline \multirow[t]{2}{*}{$30-39$} & $2.613^{* * *}$ & $2.585^{* * * *}$ & $2.576^{* * *}$ & $2.184 * * *$ & $2.461^{* *}$ \\
\hline & (4.33) & (6.01) & $(4.16)$ & (5.36) & $(3.24)$ \\
\hline \multirow[t]{2}{*}{$40-49$} & $2.296 * * *$ & $2.623 * * *$ & $2.568 * * *$ & $2.059 * * *$ & $2.217^{* *}$ \\
\hline & $(3.74)$ & $(5.95)$ & $(4.05)$ & $(4.88)$ & $(2.84)$ \\
\hline \multicolumn{6}{|l|}{ None } \\
\hline \multirow[t]{2}{*}{1 or 2} & $2.460 * * *$ & $2.706 * * *$ & $2.162 * * *$ & $2.659 * * *$ & $2.269 * * *$ \\
\hline & $(10.94)$ & $(15.54)$ & $(7.82)$ & $(13.56)$ & $(6.91)$ \\
\hline \multirow[t]{2}{*}{3 or 4} & $2.845 * * *$ & $3.280 * * *$ & $2.610 * * *$ & $3.253 * * *$ & $2.535 * * *$ \\
\hline & $(12.13)$ & $(17.92)$ & $(9.11)$ & $(15.83)$ & $(7.28)$ \\
\hline \multirow[t]{2}{*}{5 and above } & $3.171^{* * *}$ & $3.588 * * *$ & $2.949 * * *$ & $3.824 * * *$ & $3.113 * * *$ \\
\hline & $(12.92)$ & $(18.44)$ & $(9.87)$ & $(17.52)$ & $(8.54)$ \\
\hline \multicolumn{6}{|l|}{ No education } \\
\hline \multirow[t]{2}{*}{ Primary } & 0.0189 & $0.175^{*}$ & 0.177 & 0.0860 & 0.0294 \\
\hline & $(0.19)$ & $(2.06)$ & $(1.47)$ & $(0.94)$ & $(0.19)$ \\
\hline \multirow[t]{2}{*}{ Secondary } & 0.0915 & $0.465 * * *$ & 0.368 & 0.189 & -0.005 \\
\hline & $(0.57)$ & $(3.49)$ & $(1.79)$ & $(1.21)$ & $(-0.02)$ \\
\hline \multirow[t]{2}{*}{ Higher } & $0.611^{*}$ & $1.155^{* * *}$ & 0.799 & $0.710^{*}$ & 0.137 \\
\hline & $(2.04)$ & $(4.59)$ & (1.93) & $(2.13)$ & $(0.27)$ \\
\hline \multicolumn{6}{|l|}{ No paid work } \\
\hline \multirow[t]{2}{*}{ Paid work } & $1.298 * * *$ & $0.553 * * *$ & $0.531 * * *$ & $0.513 * * *$ & -0.000 \\
\hline & $(10.54)$ & $(6.11)$ & $(3.86)$ & $(5.20)$ & $(-0.00)$ \\
\hline \multicolumn{6}{|l|}{$\begin{array}{l}\text { No media } \\
\text { exposure }\end{array}$} \\
\hline \multirow[t]{2}{*}{$\begin{array}{l}\text { Low media } \\
\text { exposure }\end{array}$} & -0.0250 & $0.241^{* *}$ & -0.0912 & $0.277 * * *$ & 0.093 \\
\hline & $(-0.28)$ & (3.21) & $(-0.85)$ & $(3.38)$ & $(0.66)$ \\
\hline \multirow[t]{2}{*}{$\begin{array}{l}\text { High media } \\
\text { exposure }\end{array}$} & -0.0962 & 0.209 & -0.00921 & 0.0677 & 0.477 \\
\hline & $(-0.38)$ & $(0.99)$ & $(-0.03)$ & $(0.26)$ & $(1.28)$ \\
\hline \multicolumn{6}{|l|}{ Urban } \\
\hline \multirow[t]{2}{*}{ Rural } & $-0.612 * * *$ & -0.140 & $-0.528 * * *$ & -0.223 & -0.234 \\
\hline & $(-5.39)$ & $(-1.36)$ & $(-3.55)$ & $(-1.87)$ & $(-1.28)$ \\
\hline \multicolumn{6}{|l|}{ Less than 18} \\
\hline \multirow[t]{2}{*}{$18-24$ years } & -0.00261 & $-0.484 * * *$ & -0.162 & $-0.447 * * *$ & -0.219 \\
\hline & $(-0.02)$ & $(-4.06)$ & $(-0.99)$ & $(-3.40)$ & $(-1.03)$ \\
\hline \multirow[t]{2}{*}{25 and above } & 0.0264 & $-0.556 * * *$ & -0.0500 & $-0.482^{* *}$ & -0.253 \\
\hline & $(0.15)$ & $(-3.65)$ & $(-0.24)$ & $(-2.89)$ & $(-0.91)$ \\
\hline
\end{tabular}




\begin{tabular}{|l|c|c|c|c|c|}
\hline Poorest & & & & & \\
\hline Poorer & -0.0432 & -0.106 & -0.238 & 0.0791 & -0.291 \\
\hline Middle & $(-0.36)$ & $(-1.05)$ & $(-1.74)$ & $(0.75)$ & $(-1.58)$ \\
\hline & -0.117 & -0.128 & $-0.514^{* * *}$ & -0.0800 & $-0.745^{* * *}$ \\
\hline Richer & $(-0.92)$ & $(-1.23)$ & $(-3.32)$ & $(-0.70)$ & $(-3.38)$ \\
\hline & -0.236 & -0.0575 & $-0.677 * * *$ & -0.215 & -0.371 \\
\hline & $(-1.76)$ & $(-0.53)$ & $(-4.02)$ & $(-1.75)$ & $(-1.78)$ \\
\hline Richest & & & & & $-0.287 *$ \\
\hline & 0.245 & 0.0635 & $-0.536 * *$ & $(-2.04)$ & $(0.11)$ \\
\hline & $(1.77)$ & $(0.52)$ & $(-2.95)$ & & \\
\hline Cons & & & & & $-7.265^{* * *}$ \\
\hline & $-7.697 * * *$ & $-7.235^{* * *}$ & $-6.827 * * *$ & $-6.784 * * *$ & $(-9.58)$ \\
\hline $\mathrm{N}$ & $(-12.60)$ & $(-16.40)$ & $(-11.02)$ & $(-16.11)$ & 13,671 \\
\hline
\end{tabular}

Notes: t-statistics in parentheses $* \mathrm{p}<0.05$, ${ }^{* *} \mathrm{p}<0.01,{ }^{* * *} \mathrm{p}<0.001$. 


\begin{tabular}{|c|c|c|c|c|c|}
\hline & $\begin{array}{l}\text { Beating } \\
\text { justified If she } \\
\text { goes without } \\
\text { telling her } \\
\text { husband }\end{array}$ & $\begin{array}{l}\text { Beating } \\
\text { justified If } \\
\text { she neglects } \\
\text { children }\end{array}$ & $\begin{array}{l}\text { Beating } \\
\text { justified If } \\
\text { wife argues } \\
\text { with her } \\
\text { husband } \\
\end{array}$ & $\begin{array}{l}\text { Beating } \\
\text { justified If wife } \\
\text { refuses to have } \\
\text { sex with her } \\
\text { husband }\end{array}$ & $\begin{array}{l}\text { Beating } \\
\text { justified If } \\
\text { wife burns } \\
\text { the food }\end{array}$ \\
\hline \multicolumn{6}{|l|}{ Age group: } \\
\hline \multicolumn{6}{|l|}{$15-19$} \\
\hline \multirow[t]{2}{*}{$20-29$} & $0.130^{*}$ & -0.056 & 0.003 & -0.026 & 0.007 \\
\hline & $(2.18)$ & $(-0.98)$ & $(0.05)$ & $(-0.44)$ & $(0.10)$ \\
\hline \multirow[t]{2}{*}{ 30-39 } & -0.0866 & $-0.276 * * *$ & $-0.185 *$ & -0.0731 & -0.159 \\
\hline & $(-1.09)$ & $(-3.59)$ & $(-2.25)$ & $(-0.91)$ & $(-1.61)$ \\
\hline \multirow[t]{2}{*}{$40-49$} & $-0.229 *$ & $-0.320 * *$ & $-0.299 * *$ & -0.115 & $-0.310^{*}$ \\
\hline & $(-2.14)$ & $(-3.10)$ & $(-2.72)$ & $(-1.07)$ & $(-2.34)$ \\
\hline \multicolumn{6}{|l|}{ Children categories: } \\
\hline \multicolumn{6}{|l|}{ None } \\
\hline \multirow[t]{2}{*}{1 or 2} & -0.040 & -0.053 & 0.092 & 0.037 & 0.051 \\
\hline & $(-0.70)$ & $(-0.96)$ & $(1.54)$ & $(0.64)$ & $(0.71)$ \\
\hline \multirow[t]{2}{*}{3 or 4} & 0.0267 & 0.0606 & $0.178^{*}$ & 0.0465 & 0.124 \\
\hline & $(0.38)$ & $(0.89)$ & $(2.48)$ & $(0.66)$ & $(1.44)$ \\
\hline \multirow[t]{2}{*}{5 and above } & 0.0799 & 0.0889 & $0.203^{*}$ & 0.0501 & 0.127 \\
\hline & $(0.97)$ & (1.11) & $(2.41)$ & $(0.61)$ & $(1.25)$ \\
\hline \multicolumn{6}{|l|}{ Education: } \\
\hline \multicolumn{6}{|l|}{ No education } \\
\hline \multirow[t]{2}{*}{ Primary } & $-0.225 * * *$ & $-0.230 * * *$ & $-0.315 * * *$ & $-0.320 * * *$ & $-0.367 * * *$ \\
\hline & $(-4.24)$ & $(-4.39)$ & $(-5.88)$ & $(-6.02)$ & $(-6.00)$ \\
\hline \multirow[t]{2}{*}{ Secondary } & $-1.090 * * *$ & $-1.021^{* * *}$ & $-1.215^{* * *}$ & $-1.257 * * *$ & $-1.295 * * *$ \\
\hline & $(-13.35)$ & $(-13.34)$ & $(-14.32)$ & $(-15.23)$ & $(-12.03)$ \\
\hline \multirow[t]{2}{*}{ Higher } & $-2.814 * * *$ & $-2.566 * * *$ & $-2.695 * * *$ & $-2.384 * * *$ & $-3.006 * * *$ \\
\hline & $(-7.62)$ & $(-8.64)$ & $(-7.28)$ & $(-7.99)$ & $(-5.09)$ \\
\hline \multicolumn{6}{|l|}{ Employment for cash: } \\
\hline \multicolumn{6}{|l|}{ No paid work } \\
\hline \multirow[t]{2}{*}{ Paid work } & 0.0412 & -0.0121 & $-0.115^{* *}$ & $-0.0948 *$ & $-0.178 * * *$ \\
\hline & $(0.95)$ & $(-0.29)$ & $(-2.59)$ & $(-2.17)$ & $(-3.39)$ \\
\hline \multicolumn{6}{|l|}{ Exposure to media: } \\
\hline \multicolumn{6}{|l|}{ No media exposure } \\
\hline \multirow[t]{2}{*}{ Low media exposure } & $-0.111^{* *}$ & -0.068 & 0.024 & $-0.0946 *$ & 0.018 \\
\hline & $(-2.61)$ & $(-1.66)$ & $(0.57)$ & $(-2.20)$ & $(0.36)$ \\
\hline \multirow[t]{2}{*}{ High media exposure } & -0.0934 & 0.106 & 0.0754 & 0.0459 & 0.206 \\
\hline & $(-0.73)$ & $(0.90)$ & $(0.57)$ & $(0.36)$ & $(1.29)$ \\
\hline \multicolumn{6}{|l|}{ Residence: } \\
\hline \multicolumn{6}{|l|}{ Urban } \\
\hline \multirow[t]{2}{*}{ Rural } & $0.148^{*}$ & $0.331 * * *$ & $0.194 * *$ & $0.299 * * *$ & $0.209 *$ \\
\hline & $(2.37)$ & $(5.56)$ & $(2.99)$ & $(4.71)$ & $(2.57)$ \\
\hline \multicolumn{6}{|l|}{ Age at first marriage: } \\
\hline Less than 18 & & & & & \\
\hline
\end{tabular}




\begin{tabular}{|l|c|c|c|c|c|}
\hline $18-25$ years & 0.007 & -0.005 & 0.009 & 0.0331 & 0.128 \\
\hline 25 and above & $(0.09)$ & $(-0.07)$ & $(0.11)$ & $(0.39)$ & $(1.24)$ \\
\hline & 0.0850 & 0.054 & -0.0337 & -0.084 & -0.001 \\
\hline Wealth Index: & $(0.75)$ & $(0.50)$ & $(-0.29)$ & $(-0.76)$ & $(-0.01)$ \\
\hline Poorest & & & & \\
\hline Poorer & & & & & \\
\hline & $-0.178^{* *}$ & -0.0917 & $-0.157 * *$ & $-0.137 *$ & $-0.180^{* *}$ \\
\hline Middle & $(-3.08)$ & $(-1.61)$ & $(-2.67)$ & $(-2.35)$ & $(-2.65)$ \\
\hline & $-0.262^{* * *}$ & $-0.137 *$ & $-0.284 * * *$ & $-0.310^{* * *}$ & $-0.272^{* * *}$ \\
\hline Richer & $(-4.40)$ & $(-2.35)$ & $(-4.68)$ & $(-5.17)$ & $(-3.85)$ \\
\hline & $-0.328 * * *$ & $-0.218^{* * *}$ & $-0.302 * * *$ & $-0.288^{* * *}$ & $-0.344 * * *$ \\
\hline Richest & $(-5.33)$ & $(-3.62)$ & $(-4.82)$ & $(-4.67)$ & $(-4.63)$ \\
\hline & $-0.433^{* * *}$ & $-0.361^{* * *}$ & $-0.486 * * *$ & $-0.474 * * *$ & $-0.516 * * *$ \\
\hline Cons & $(-6.20)$ & $(-5.36)$ & $(-6.75)$ & $(-6.71)$ & $(-5.88)$ \\
\hline & -0.124 & 0.111 & $-0.202^{*}$ & 0.0142 & $-0.875^{* * *}$ \\
\hline $\mathrm{N}$ & $(-1.29)$ & $(1.19)$ & $(-2.06)$ & $(0.15)$ & $(-7.46)$ \\
\hline
\end{tabular}

Notes: t-statistics in parentheses ${ }^{*} \mathrm{p}<0.05,{ }^{* *} \mathrm{p}<0.01,{ }^{* * *} \mathrm{p}<0.001$. 